(Prehl'adový článok)

\title{
Characteristic of the Local Factors in the Aetiology of the Burning Mouth Syndrome
}

(Review)

Riznič M., Konečná A., D̆urovič E., Vodrážka J.

SKZL - Regionálna komora zubných lekárov v Košiciach, výbor pre vzdelávanie

I. stomatologická klinika LF UK a OUZA, Bratislava

\section{SÚHRN}

Obsah oznámenia: Autori opisujú prehl'ad lokálnych faktorov, ktoré sú v klinickej súvislosti so syndrómom pálenia jazyka (BMS). Ide o lézie na povrchu jazyka, ktorých výrazným symptómom je pálenie.

Autori opisujú lézie, ktoré sa tvoria: mechanickým alebo chemickým dráždením, habitualnymi parafunkciami, kontaktnou alergiou na kovy, bakteriálnou, pliesňovou a vírusovou infekciou, suchostou v ústach, slizničnými léziami a kombinovanými stavmi.

Prehl'ad faktorov je usporiadaný v tabul'ke, vrátane spresnenia postupu bolestivosti a pálenia. Charakteristiku lézií dokumentuje klinický fotografický materiál.

Klúčové slová: syndróm pálenia jazyka - BMS - lokálne faktory - klinické obrazy

\section{SUMMARY}

Background: In this paper, authors are presenting all the local factors which are in clinical relation with burning mouth syndrome (BMS). Usually it is all the lesions at the surface of tongue with the most significant syndrome of burning.

Authors are describing lesions which originate during mechanical or chemical iritation, habitual parafunction, as contact metal allergies, bacterial, virus or mycotical infection, dryness of oral mucosa and it's lesions or combination of this conditions.

Those factors are listed in a table summary with a more detailed spread of pain and burning.

These lesions are documented with many clinical pictures.

Keywords: burning mouth syndrome - BMS - local factors - clinical picture

\section{LOKÁLNE FAKTORY V ETIOLÓGII SYNDRÓMU PÁLENIA JAZYKA}

Zaradenie etiologických lokálnych faktorov medzi faktory syndrómu pálenia jazyka (BMS) značne prispelo k ul'ahčeniu diferenciálnej diagnostiky a aj k možnosti zlepšenia liečebných postupov tohto náročného chorobného stavu.
Aby sme mohli vykonat' kvalitné zaradenie BMS medzi atypické bolesti, je potrebné vykonat' pozorné vyšetrenie slizníc ústnej dutiny, prijat podrobnú osobnú anamnézu a analyzovat' údaje o pálčivých pocitoch na jazyku. Pre posudzovanie pálenia a klinických príznakov, odporúčame postupovat' podl'a nasledovných kritérií (tab. 1). 
Tab. 1 Prehl'ad lokálnych faktorov v etiologii syndrómu pálenia jazyka

\begin{tabular}{|c|}
\hline \begin{tabular}{c} 
Mechanické alebo chemické dráždenie \\
Habitualne parafunkcie \\
\hline Kontaktná alergia na kovy
\end{tabular} \\
\hline Bakterialne, pliesňové a vírusové infekcie \\
\hline Suchost' v ústach \\
\hline Slizničné lézie \\
\hline Kombinované lézie
\end{tabular}

Pri analýze lokálnych faktorov do popredia sa bolestivost' dostáva iba zriedkavo, aj to na krátku dobu, a do popredia sa dostáva pálčivý pocit rôznej intenzity a rôzneho trvania.

Jednou z najčastejších lézií je prehíbenie alebo nedokonalé vyvinutie sulcus medianus. Ked' dochádza ku jeho prehíbeniu, jeho vnútorné okraje sú hladké bez prítomnosti filiformnych papíl a v týchto miestach ich prirodzená výmena viazne. Do tejto fissúry sa zachytáva tkaninový detritus a mikroorganizmy. Najčastejšie pozorujeme rozmnoženie sa Candida albicans, tvorí sa jeho silná vrstva a často dá základy ku tvorbe bielo žltému povlaku nerovnakej hrúbky.

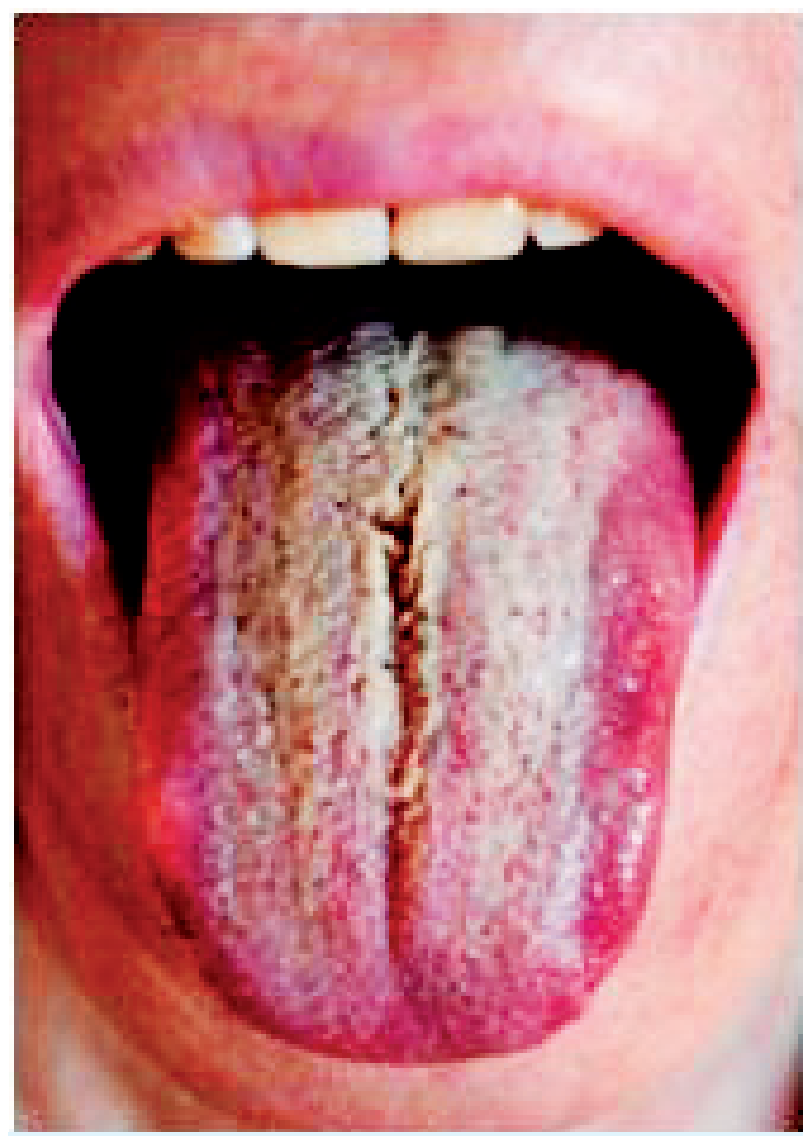

Obr. 1 Prechod patologicko-zmnoženého povlaku do žltých nakopenin filiformných papíl, z ktorých v strednej ryhe tela jazyka sa diferencuje linqua vilosa žltej farby (Timková)

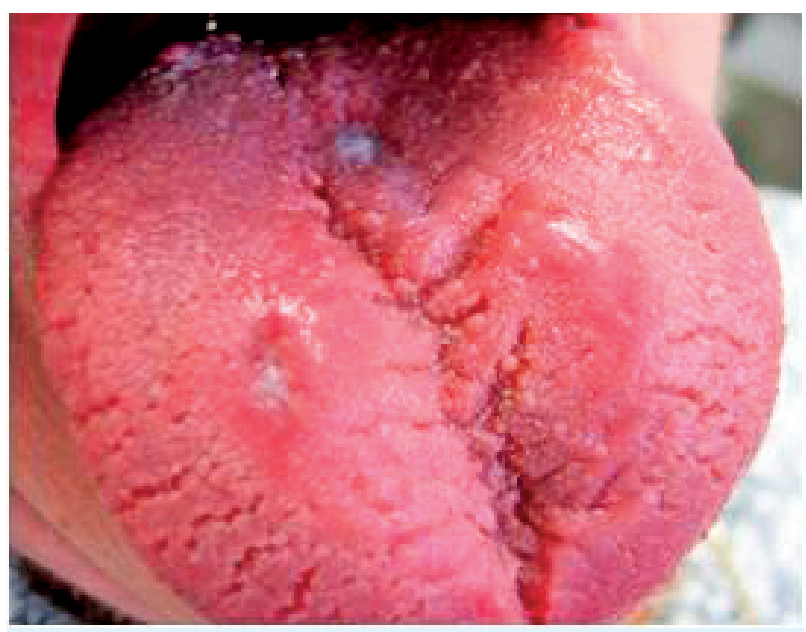

PRAKTICKÉ

ZUBNÍ

LÉKAŘSTVÍ,

ročník 65

2017, 2,

s. $26-30$

Obr. 2 Linqua plicata. Rýhovanie je lokalizované do tela jazyka a jeho pravého okraja. Na pravej polovine začína atrofická lichenifikácia (Vodrážka)

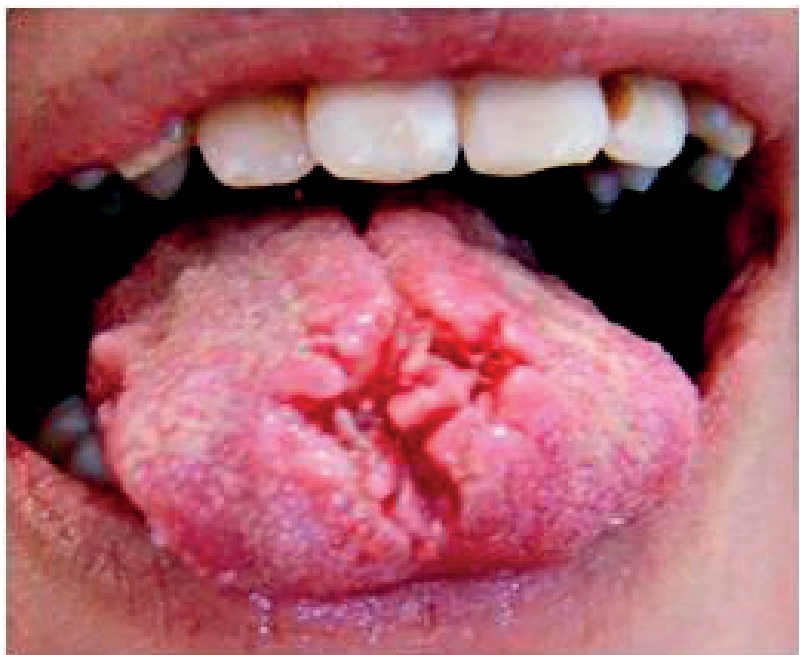

Obr. 3 Linqua plicata. Hlboké trhliny sú prítomné na hrote a trla jazyka. V týchto miestach často vznikajú druhotné povrchové zápaly (Vodrážka)

Pacienti subjektívne pocitujú prítomnost cudzieho telesa a mierny zápach z úst. Do popredia sa dostáva pálenie $\mathrm{v}$ centre tela jazyka, ktoré začína obyčajne na mechanické alebo chemické podráždenie potravou, intenzita pálenia nie je silná, má kontinuálny charakter a postupne ustupuje po ukončení žuvania potravy. Opakované podráždenie má menšiu intenzitu. Pocit pálenia sa zvyšuje pri fajčení cigariet (obr. 1). Povlak na povrchu jazyka je obmedzený, do periférie, ale môže sa rozširovat' smerom k radixu linguae.

Ďalšia tvorba fissúr je na povrchu jazyka bez povlaku. Sulcus medianus je značne prehíbený, avšak menej ako v predošlom prípade. Od jeho stredu, peri- 


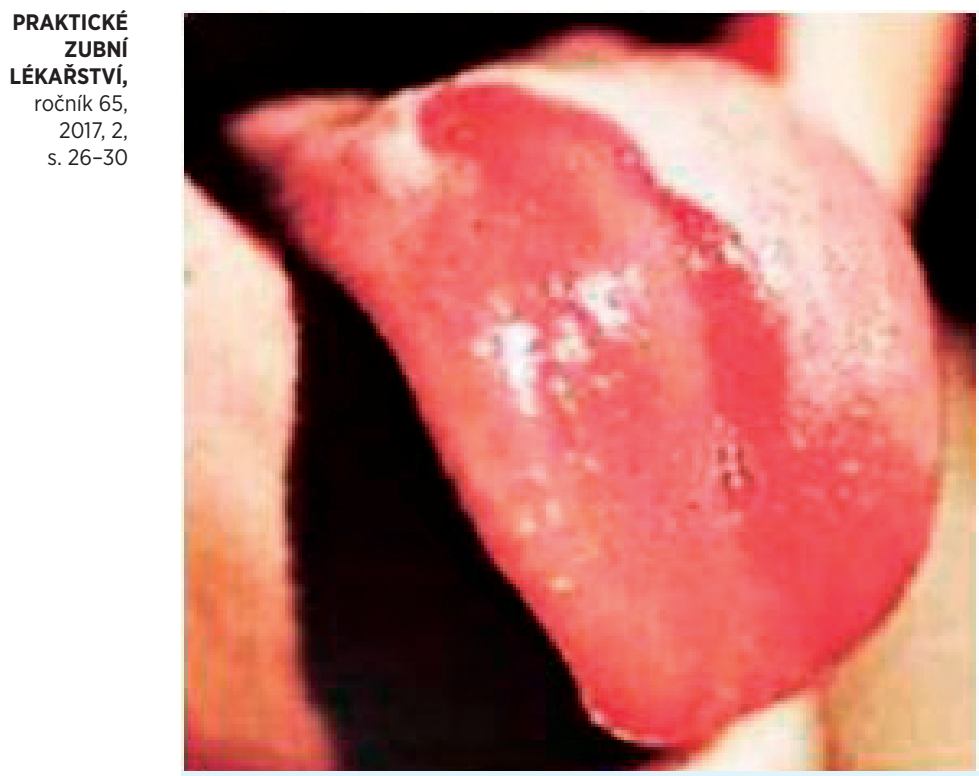

Obr. 4 Linqua geographica. Na tento povrch sa pridružuje povlak patologicky zmnožený a povrchová erózia na hrote jazyka

férne k okrajom jazyka sa rozbiehajú d’alšie málo hlboké brázdy smerom k okrajom jazyka. Subjektívne chýba pocit cudzieho telesa a pálenie je výrazne obmedzené alebo chýba. Môžu sa však objavit na tele jazyka skromné okrúhle lézie z porúch keratinizácie alebo epitelialných defektov, ktoré pacienti vedia vyhmatat' a tieto vykazujú miernu prchavú bolestivost' na mechanické podráždenie (obr. 2).

Z lokálnych faktorov sme často svedkami následkoch habitualnych parafunkcií, ktorými vytvorené fissúry na povrchu jazyka sa zhoršujú tak, že traumatizáciou sa zväčšujú do šírky a do híbky (obr. 3). U týchto stavov povlak chýba, ale sa zvyšuje pálenie na podráždenie a niekedy, ked' sú fissúry hlboké, aj spontánne. Pálenie má kolísavú intenzitu, dlho trvá a často prechádza do tupej bolesti. Bolest' pri stravovaní sa môže menit' a prechádzat' do ostrých bolestných pocitov. Pri týchto stavoch boli pozorované aj zväčšenia pomerne malých brázd, ked' následkom traumy sa povrch jazyka edematicky zväčšil.

Medzi lokálne faktory syndrómu pálenia jazyka zarad'ujeme kontaktné alergie na stomatologické kovy. V súčasnosti tieto prejavy sú vzácne, nakol'ko používané kovy sú biologicky inertné a v stomatológii sa používajú v obmedzenom počte. Používa sa amalgam a chromniklové zliatiny. Sú však nahradzované inými hmotami. Ak sa však kontaktné alergické lézie vyskytnú, sú lokalizované obyčajne na hrote jazyka ako malé červené pupence. Sú to zápaly hrotov filiformných papíl, alebo sa nachádzajú na bokoch jazyka, vo forme bieleho tenkého pásu. Lézie krátko trvajú a slabo pália.

Častou léziou je lingua geographica. Vedúcim príznakom je pálenie jazyka obyčajne počas stravovania alebo ako reakcia na kyslé a korenené, prípadne paprikované jedlá. Pálenie je značne silné a trvá po dobu pôsobenia dráždivej potravy. Podmienkou však je, aby výmenou filiformných papíl v regeneračnom procese bol zasiahnutý väčší úsek povrchu tela jazyka (obr. 4).

Nepríjemnou formou GT je glossitis areata migrans. Táto lézia sa môže prejavit' aj bez prítomnosti povlaku jazyka, vo forme okrúhlych erozií. Lézie sú značne bolestivé, najmä pri korenených jedlách, kyslých nápojoch a pri mechanickom podráždeniu. Lézie pozorujeme pri infekciach Helicobakter pylori a ich remisie a hojenie takmer kopíruje stav infekcie sliznice žalúdka. Pálenie je neprijemne ostré, má striedavú intenzitu a trvá po dobu prítomnosti erózií na povrchu jazyka. Pálenie sa rovnako vyskytuje ako pri čerstvých infekciach, ako aj pri následkoch eradikačných liečebných postupoch. Dokonca sú skúsenosti s tým, že lézie sa môžu vo forme glossitis areata migrans vyskytovat' aj pri gastroezofageálnych refluxoch (obr. 5).

V posledných rokoch sme svedkami toho, že sa zvyšuje výskyt orálnych infekcií vyvolaných Candida albicans. Orálne kandidózy pozorujeme u pacientov v strednom veku s maximom výskytu u žien nad 40 rokov. Orálne kandidózy majú viac foriem, ale

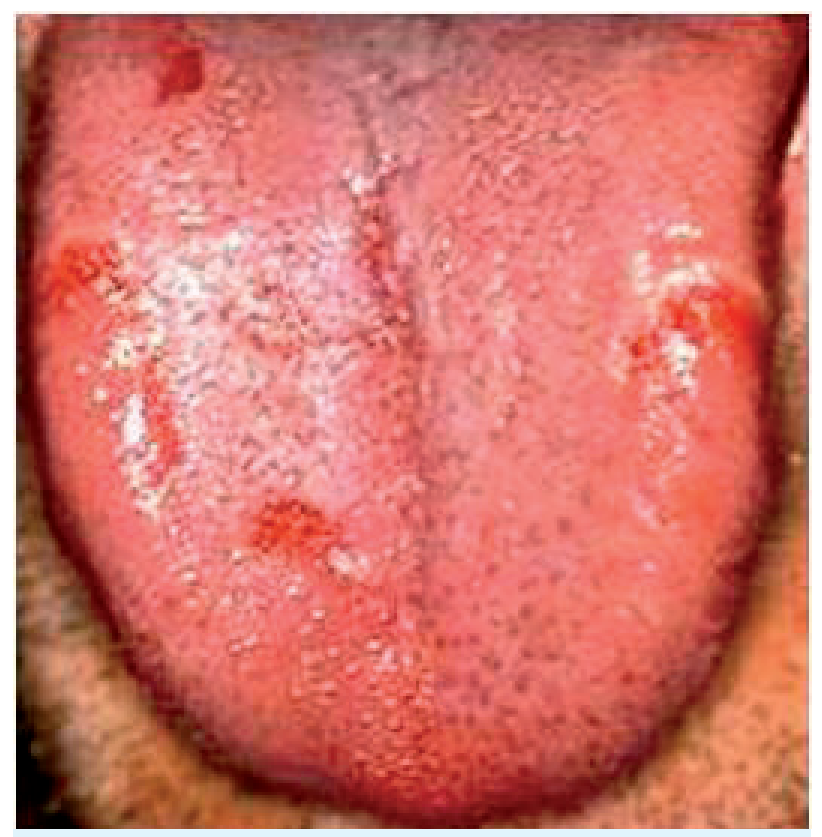

Obr. 5 Povlak je normálný, na povrchu jazyka sú čerstvé erozie. Stav je u recidívnej infekcii Helikobakter pylori (Ďurovič) 


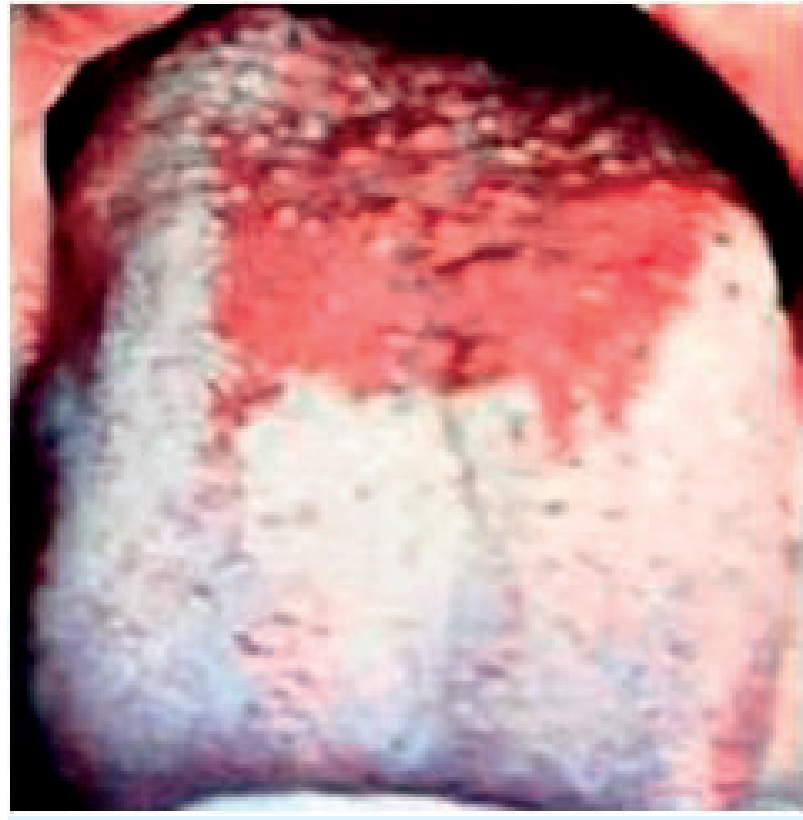

Obr. 6 Linqua plicata. Obmedzený počet rýh je lokalizovaný na tele jazyka. Ryhy nie sú hlboké a stav nevyvoláva tažkosti

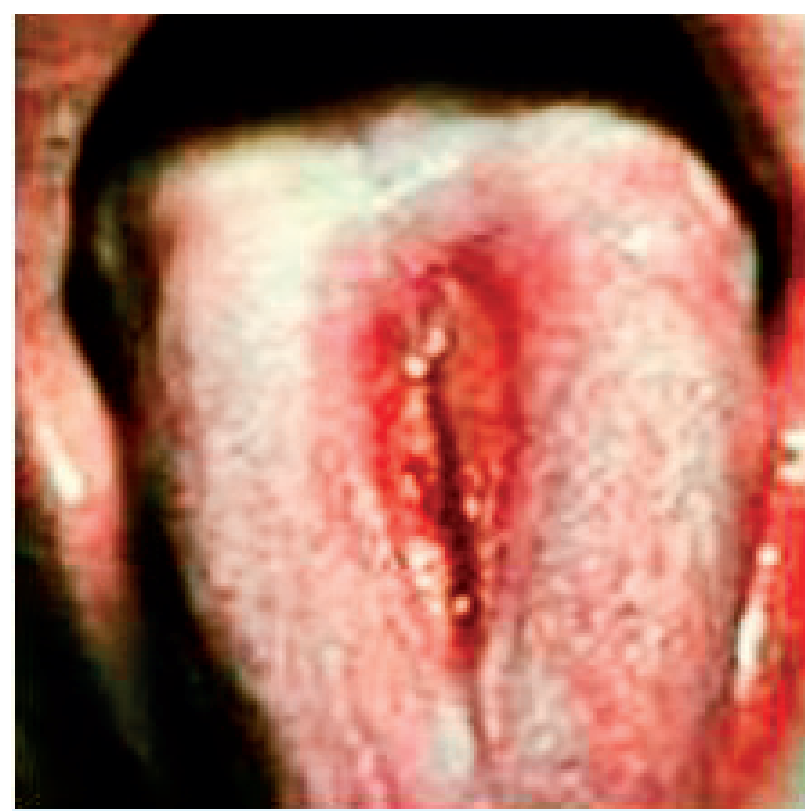

Obr. 7 Patologicky zmnožený povlak jazyka. Jeho olupovanie začína na koreni jazyka a pripomína mapovitý jazyk

najčastejšie sa vyskytuje vo forme glossitis rhombica mediana s lokalizáciou na koreni jazyka. V tomto mieste sa vyskytuje ružové pole, ktoré môže byt' hladké alebo laločnaté, od ktorého smerom k apexu sa postupne odlupuje l'ahký povlak bohatý na kultúry kandíd. Smerom distálnym ostáva miesto bez povlaku, ktoré kontinuálne mierne pálí. Pocity pálenia majú tendenciu sa znižovat úmerne s postupom olupovania povlaku a niekedy aj pri častejšom prehltávaní (obr. 6). Sú však aj stavy, ktoré tieto tažkosti nevyvolávajú alebo ich intenzita je vel'mi malá. U mužov fajčiarov povlak v tomto mieste môže menit' farbu a zaujímavé je, že subjektívne tažkosti sa znižujú.

V tejto skupine lokálnych faktorov lézie vírusového pôvodu sú vel'mi vzácne a aj údaje o nich v literatúre sú značne skúpe. Nemožno však vylúčit' možnost́ erupcie vnútro ústnej infekcie vírusom herpesu simplex alebo humánnym papiloma vírusom.

Suchost' v ústach je d'alším lokálnym faktorom, ktorý vyvolá syndróm pálenia jazyka. Pálenie je povrchové a jeho intenzita závisí na trvaní suchosti. Takéto stavy môžeme pozorovat' už pri hyposalivačnom syndrome, najčastejšie liekového pôvodu.

Slizničné lézie, ktoré sa vyskytujú samostatne na jazyku sa považujú za časté faktory BMS. Ide vlastne o aphthosis major s lokalizáciou na povrchu tela jazyka, na jeho bokoch alebo na spodine. Je to dlho trvajúca nehojivá zvredovatelá afta. Lézia je obyčajne okrúhleho alebo pozdľžneho tvaru. Začína neurčitými príznakmi. Pacienti udávajú pocit výskytu malého hrbol'ku alebo malej vezikuly, ktoré sa rozpadnú, a vznikne povrchový defekt v epitelovom kryte. Nastáva silné pálenie, ktoré sa zväčšuje po mechanickom podráždení, pri hovore a pri stravovaní. Pálenie často prechádza do bolesti. Pálenie dlho trvá, vlastne po dobu trvania lézie v epitelovom kryte (obr. 7).

Poslednú dobu častým výskytom je prejav eythema exsudativum multiforme a to tej formy, ktorá sa izolovane vyskytuje na častiach jazyka (obr. 8). Je to rozsiahla lézia izolovane na boku jazyka, má belasú alebo žltú farbu, dá sa odlúpnut' s miernym povrchovým krvácaním alebo bez neho a ostáva sliznica živo červenej farby. Z tažkostí dominuje silné pálenie, podobne ako pri aphtosis major. Ak sa vyskytne bolestivost', táto je silná a obyčajne provokovaná mechanickým, prípadne chemickým podráždením.

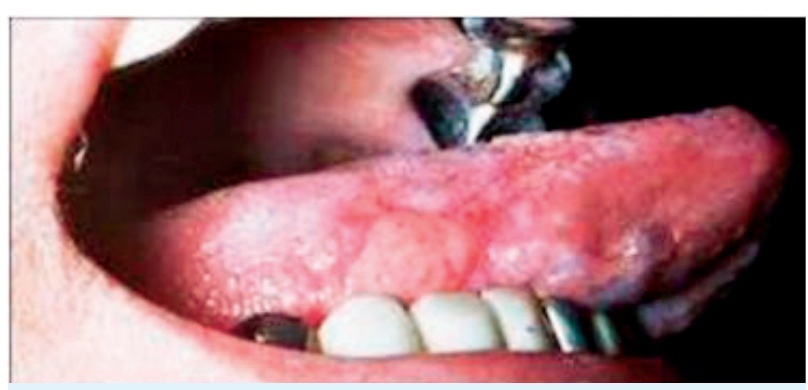

Obr. 8 Glositis areata migrans. Prítomný je patologicky zmnožený povlak s erozívnymi políčkami. Stav je pri infekcii Helikobakter pylori
PRAKTICKÉ ZUBNÍ LÉKAŘSTVÍ, ročník 65 , 2017, 2, s. $26-30$ 


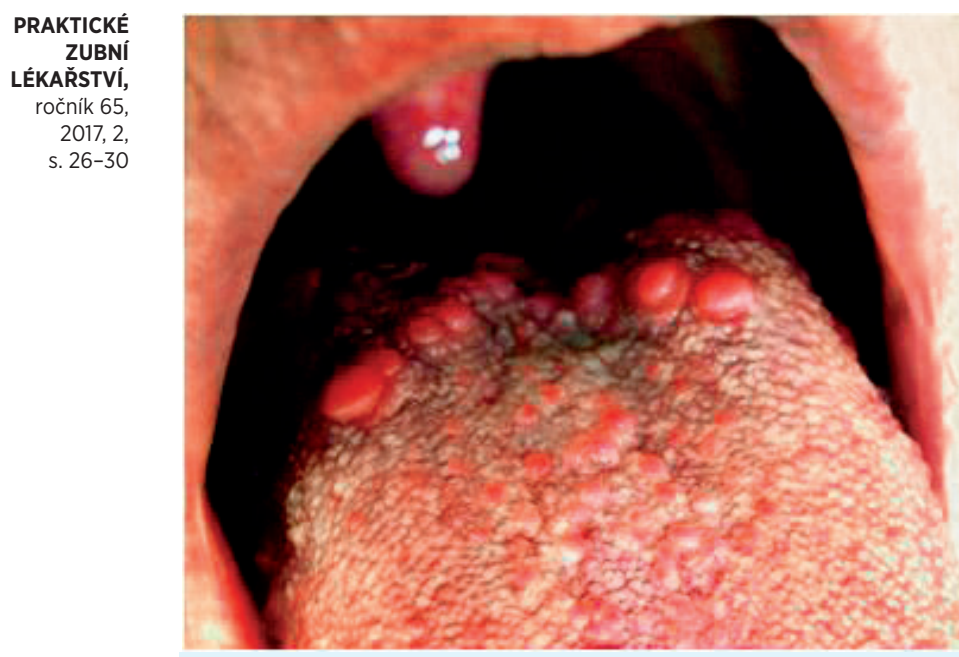

Obr. 9 Hyperplasticky a zápalovo zmenené papilae circumvalatae. Zápal postihuje aj chutové poháriky a čast filiformných papíl. Stav je u ezofageálnom refluxe (Timková)

Podobné lézie môžeme pozorovat' pri lokálnych tepelných škodách. Často sú to popáleniny horúcim kovovým príborom. Pri nich pocit pálenia je na začiatku tvorby lézie, neskôr pálenie ustupuje, ale lézia trvá a hojí sa postupne, Ak sa pálenie mení do pocitu bolesti, stav podlieha sekundárnej infekcii, čo sa považuje ako komplikácia.

Posledným lokálnym faktorom sú tzv. kombinované lézie. Ide o stavy, kedy sa na povrchu jazyka vyskytujú fissúry spolu s lingua geographica a časom sa pridruží glossitis rhombica mediana, prípadne povlak patologicky zmnožený (obr. 9). Často rozsiahlost' lézii je v rozpore so subjektívnymi symptómami BMS. Ťažkosti sú d'aleko menšie alebo chýbajú.

\section{ZÁVER}

Lokálne faktory v problematike BMS sú pomerne časté a zarad'ované medzi úspešne liečitel'né stavy. Syndróm pálenia jazyka po ústupe lokálnych faktorov ustúpi, tažkosti sú obyčajne krátkodobé a z týchto stavov sa vel'mi vzácne transformujú iné príčinné súvislosti v BMS. Preto aj liečebné postupy sú jednoduché a úspešné.

\section{LITERATÚRA}

1. Balasubramaniam, R., Klasser, G. D., Delcanho, R.: Separating oral burning from burning mouth syndrome: unravelling a diagnostic enigma. Aust. Dent. J., 2009.
2. Brailo, V., Vuèiæeviæ-Boras, V., Alajbeg, I. Ž., Alajbeg, I., Lukenda, J., Eurkoviæ, M. Oral burning symptoms and burning mouth syndromesignificance of different variables in 150 patients. Med. Oral Patol. Oral Cir. Bucal., roč. 11, 2006, s. E252-255.

3. Cavalcanti, D. R., Birman, E. G., Migliari, D. A., da Silveira, F. R.: Burning mouth syndrome: clinical profile of brazilian patients and oral carriage of Candida species. Braz. Dent. J., roč. 18, 2007, č. 4, s. 341-345.

4. Cerchiari, P. D., Dutra de Moricz, R., Sanjar, F. A.: Burning mouth syndrome: etiology. Rev. Bras. Otorrinolaringol., roč. 72, 2006, č. 3, s. 419-424.

5. Crow, H. C., Gonzalez, Y.: Burning mouth syndrome. Oral Maxillofac. Surg. Clin. North Am., roč. 25, 2013, č. 1, s. 67-76.

6. Ďurovič, E., Timková, S., Riznič, M.., Minčík, J., Konečná, A.: Orálne zdravie pacientov s diabetes mellitus 2. typu. Stomatológ, roč. 26, 2016, č. 2, s. 38-45.

7. Ďurovič, E., Timková, S., Riznič, M., Minčík, J., Konečná, A.: Skupina chorôb erythema exsudativum multiforme. Stomatológ, roč. 26, 2016, č. 2, s. 47-52.

8. Kamala, K. A., Sankethguddad, S., Sujith, S. G.: Burning mouth syndrome. Indian J. Palliat. Care, roč. 22, 2016, č. 1, s. 74-79.

9. López-Jornet, P., Camacho-Alonso, F., Andujar-Mateos, P., Sánchez-Siles, M., Gómez-Garcia, F.: Burning mouth syndrome: an update. Med. Oral Patol. Oral Cir. Bucal., roč. 15, 2010, č. 4, s. e562-568.

10. Rodriguez-Cerdeira, C., Sanchez-Blanco, E.: Treatment of burning mouth syndrome with amisulpride. J. Clin. Med. Res., roč. 4, 2012, č. 3, s. 167-171.

11. Scala, A. L., Checchi, M., Montevecchi, I.: Update on burning mouth syndrome: Overview and patient management. Crit. Rev. Oral Biol. Med., roč. 14, 2003, č. 4, s. 275-291.

12. Spanemberg, J. C., Cherubini, K., de Figueiredo, M. A., Yurgel, L. S., Salum, F. G.: Aetiology and therapeutics of burning mouth syndrome: an update. Gerodontology, roč. 29, 2012, č. 2, s. 8489.

13. Steele, J. C.: The practical evaluation and management of patients with symptoms of a sore burning mouth. Clin. Dermatol., roč. 34, 2016, Č. 4, s. 449-457.

14. Sun, A., Wu, K. M., Wang, Y. P., Lin, H. P., Chen, H. M., Chiang. C. P.: Burning mouth syndrome: a review and update. J. Oral Pathol. Med., roč. 42, 2013, č. 9, s. 649-655.

15. Timková, S., Riznič, M., Minčík, J., Ďurovič, E., Kizek, P.: Ochorenia jazyka. Košice, Vydavatel'stvo JES, 2016.

16. Timková, S., Ďurovič, E., Minčík, J., Riznič, M.: Systémové herpetické infekcie a ich prejavy na slizniciach ústnej dutiny. Stomatológ, roč. 26, 2016, č. 1, s. 44-52.

\section{Doc. MUDr. Eugen Ďurovič, Dr.Sc.}

Hlinkova 12

04001 Košice

Slovenská republika

e-mail: durovic.eugen@gmail.com 